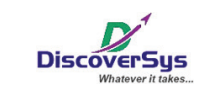

Published by DiscoverSys

\section{Risk factors of breast cancer in women at Sanglah General Hospital}

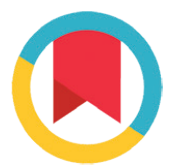

CrossMark

\section{ABSTRACT}

Breast cancer is the most common cancer that found in women. More than 800,000 newly identified breast cancer cases are diagnosed in the whole world annually. In Indonesia, breast cancer is the second common cancer among women after servical cancer. Risk factors of breast cancer include pregnancy history, age at first pregnancy, breast feeding history, utilization of hormonal birth control, menarche history, genetic tendencies and past breast infections. This study aimed to assess the risk factors that contribute to increasing breast cancer incidence in cancer patients at Sanglah Hospital. Research used a matched paired case-control study with a sample of 38 female breast cancer patients and 38 female noncancer patients with similar backgrounds, age and address. Data was collected through questionnaire. Data analysis was conducted using bivariate with McNemar test and multivariate analysis using logistic regression. The result of bivariate analysis showed that risk factors that increased breast cancer included breast disease history $(O R=13.5 ; 95 \% \mathrm{Cl}: 3.21-56.77)$ and genetic tendencies $(O R=8$; 95\% Cl: 1.84-34.79). The result of multivariate analysis showed that the only significant risk factor was breast infection history $(\mathrm{OR}=43.19 ; 95 \% \mathrm{Cl}: 8.79-212.27)$. Future recommendations include increased health promotion about the importance of early detection and screening, as well as information related to the dangers of breast infection/disease. National policy regarding access to mammography facilities should also be prioritised.

Keywords: breast cancer, risk factors, case control study, Sanglah Hospital Cite This Article: Trisnadewi, Sutarga, I.M., Duarsa, D.P. 2013. Risk factors of breast cancer in women at Sanglah General Hospital. Public Health and Preventive Medicine Archive 1(2): 139-144. D0I:10.15562/phpma.v1i2.177

\title{
Faktor risiko kanker payudara pada wanita di RSUP Sanglah Denpasar
}

'Public Health Postgraduate Program Udayana University, ${ }^{2} S$ chool of Public Health Faculty of Medicine Udayana University, ${ }^{3}$ Department of Community and Preventive Medicine, Faculty of Medicine, Udayana University, ${ }^{4}$ Wira Medika Health Science Education Program PPNI Bal

"Correspondence to:

Trisnadewi, Public Health

Postgraduate Program Udayana University, Wira Medika Health Science Education Program PPNI Bali trisna_wika@yahoo.co.id
Kata kunci: kanker payudara, faktor risiko, kasus kontrol, RSUP Sanglah

Kutip artikel ini:Trisnadewi, Sutarga, I.M., Duarsa, D.P. 2013. Faktor risiko kanker payudara pada wanita di RSUP Sanglah Denpasar. Public Health and Preventive Medicine Archive 1(2): 139-144. D0I:10.15562/phpma.v1i2.177 


\section{PENDAHULUAN}

Kanker payudara adalah sekelompok sel tidak normal pada payudara yang terus tumbuh berlipat ganda. Sel ini pada akhirnya akan membentuk benjolan di payudara. Apabila tidak dibuang atau terkontrol, sel-sel kanker bisa menyebar (metastase) pada bagian-bagian tubuh lain dan dapat menyebabkan kematian. ${ }^{1,2}$ Kanker bisa tumbuh di dalam kelenjar susu, saluran susu, jaringan lemak dan jaringan ikat pada payudara. Kanker payudara umumnya menyerang wanita.

Setiap tahun, lebih dari 800.000 kasus baru kanker payudara didiagnosis di seluruh dunia. Insiden kasus kanker payudara di Indonesia terus mengalami peningkatan setiap tahun. Di Indonesia, kanker payudara adalah kanker terbanyak kedua pada wanita sesudah kanker leher rahim dan merupakan kanker yang menyerang sebagian besar wanita. Sedangkan pria hanya memiliki $1 \%$ risiko terkena kanker payudara. Terdapat kecenderungan peningkatan angka kejadian kanker payudara dari tahun ke tahun dimana angka kejadiannya mencapai 26 per 100.000 perempuan, disusul kanker leher rahim dengan 16 per 100.000 perempuan. ${ }^{3,4}$

Di Bali dengan menggunakan data sekunder yang dilaporkan RSUP Sanglah Denpasar didapatkan data jumlah kunjungan pasien kanker payudara pertahun rata-rata sekitar 668 kasus. Jumlah pasien yang meninggal tahun 2012 adalah sebanyak 153 pasien. Data yang diperoleh dalam tiga bulan terakhir yaitu Bulan Oktober-Desember tahun 2012 terdapat kasus kanker payudara sebanyak 166 orang yang terdiri dari 4 pasien lakilaki dan sisanya adalah perempuan.

Kejadian kanker payudara sangat dipengaruhi oleh berbagai faktor risiko. Salah satu yang cukup penting adalah jenis kelamin. Wanita berisiko 100 kali lebih tinggi dibandingkan dengan laki-laki untuk terserang kanker payudara. Faktor risiko lain yang diduga meningkatkan risiko kanker payudara adalah riwayat kehamilan, usia saat hamil anak pertama $>30$ tahun, riwayat menyusui anak $>1$ tahun, penggunaan kontrasepsi hormonal yang lama ( $\geq 12$ tahun), riwayat menarche pada usia $\leq 12$ tahun, riwayat adanya keluarga dengan kanker payudara serta riwayat adanya penyakit pada payudara sebelumnya (infeksi atau tumor). Sampai saat ini tidak ada satupun penyebab spesifik dari kanker payudara. Serangkaian faktor genetik, hormonal dan lingkungan diduga saling berinteraksi dalam terjadinya kanker. Masih banyak faktor risiko lain yang diduga dapat meningkatkan insiden kanker payudara, namun penyebab pasti dari penyakit ini belum diketahui dengan pasti..$^{5-7}$
Adanya kecenderungan peningkatan jumlah penderita kanker payudara di Indonesia, khususnya di Bali serta efek yang ditimbulkan sangat besar meliputi medis, klinis, psikologis serta pembiayaan, maka upaya komprehensif untuk mencegah terjadinya kanker payudara sangat diperlukan. Penelitian ini bertujuan untuk mengetahui faktorfaktor risiko yang berkaitan dengan kejadian kanker payudara pada wanita di RSUP Sanglah Denpasar.

\section{METODE}

Penelitian ini menggunakan desain kasus-kontrol berpasangan yang dilaksanakan dari Bulan MaretMei 2013. Sampel kasus adalah pasien kanker payudara yang berobat di Poliklinik Onkologi RSUP Sanglah Denpasar dan sampel kontrol adalah pasien wanita tanpa kanker payudara yang dirawat di ruang rawat inap RSUP Sanglah Denpasar. Jumlah sampel kasus dan kontrol masing-masing adalah 38 orang. Sampel dipilih secara purposive sampling.

Variabel bebas dalam penelitian ini meliputi riwayat tidak pernah mengalami proses kehamilan, usia saat pertama hamil, riwayat menyusui, penggunaan kontrasepsi hormonal, riwayat menarche, riwayat keluarga dengan kanker payudara dan riwayat penyakit pada payudara. Variabel tergantung adalah kejadian kanker payudara. Pengumpulan data dilakukan dengan cara wawancara dengan menggunakan pedoman wawancara untuk menggali faktor risiko berkaitan dengan kejadian kanker payudara.

Semua data dalam penelitian dibuat menjadi data kategorikal. Riwayat tidak pernah mengalami kehamilan dibagi menjadi dua yaitu pernah mengalami kehamilan dan tidak pernah mengalami kehamilan, usia saat hamil pertama dikategorikan menjadi $\geq 30$ tahun dan $<30$ tahun. Riwayat menyusui dikategorikan menjadi menyusui $<1$ tahun dan menyusui $\geq 1$ tahun, riwayat penggunaan kontrasepsi hormonal dikategorikan menjadi penggunaan kontrasepsi hormonal $\geq 12$ tahun dan penggunaan kontrasepsi hormonal $<12$ tahun, usia menarche dikategorikan menjadi menarche $\leq 12$ tahun dan menarche $>12$ tahun. Riwayat kanker payudara pada keluarga dikategorikan menjadi ada keluarga yang menderita kanker payudara dan tidak ada keluarga yang menderita kanker payudara. Riwayat penyakit pada payudara dikategorikan menjadi apabila sebelumnya ada penyakit pada payudara (infeksi, tumor, operasi tumor) dan apabila sebelumnya tidak ada penyakit pada payudara.

Analisis data dilakukan secara bertahap meliputi analisis univariat, bivariat dan multivariat. Analisis 
univariat untuk melihat distribusi frekuensi dari masing-masing variabel, dan dilanjutkan dengan analisis bivariat untuk melihat hubungan antara variabel tergantung dengan masing-masing variabel bebas. Sedangkan analisis multivariat untuk mencari variabel bebas yang memiliki risiko paling kuat terhadap variabel tergantung. Penelitian ini telah dinyatakan laik etik oleh Komisi Etik Penelitian Fakultas Kedokteran Universitas Udayana dan Rumah Sakit Umum Pusat Sanglah Denpasar.

\section{HASIL}

Sebanyak 76 sampel yang terpilih dalam penelitian ini dapat berpartisipasi dengan baik dan tidak ada penolakan. Tabel 1 menunjukkan karakteristik demografi responden. Pada Tabel 1 dapat dilihat bahwa responden pada kelompok kasus maupun kontrol, paling banyak berada pada kelompok umur 41-50 tahun yaitu 21,1\%. Kelompok kasus sebagian besar bekerja sebagai ibu rumah tangga
(32,9\%) sedangkan pada kelompok kontrol pekerjaan responden yang paling banyak adalah sebagai pegawai swasta (22,4\%). Baik pada kelompok kasus maupun kelompok kontrol paling banyak ditemukan berasal dari Kota Denpasar yaitu sebanyak 18,4\%. Apabila dilihat dari tingkat pendidikan, sebagian besar responden baik pada kelompok kasus maupun kontrol adalah pada jenjang SMA yaitu sebanyak $23,7 \%$ pada kasus dan sebanyak $19,7 \%$ pada kelompok kontrol.

Tabel 2 menunjukkan hasil analisis bivariat terhadap faktor-faktor yang signifikan meningkatkan kejadian kanker payudara adalah riwayat kanker payudara pada keluarga dan riwayat adanya penyakit pada payudara. Faktor lainnya terbukti tidak bermakna meningkatkan risiko kanker payudara. Semua faktor risiko tersebut kemudian dianalisis secara multivariat, dan ditemukan bahwa hanya variabel riwayat penyakit pada payudara yang bermakna meningkatkan risiko kanker payudara pada wanita dengan $\mathrm{OR}=43,19$ (95\%CI: 8,79-212,27) dan nilai $\mathrm{R}^{2}=0,574$.

Tabel 1 Distribusi frekuensi subjek penelitian berdasarkan kelompok umur, pekerjaan, alamat, dan pendidikan antara kasus dan kontrol

\begin{tabular}{|c|c|c|c|c|c|}
\hline \multirow[b]{2}{*}{ Karakteristik } & \multicolumn{2}{|c|}{ Kasus } & \multicolumn{2}{|c|}{ Kontrol } & \multirow[b]{2}{*}{ Nilai p } \\
\hline & Jumlah & (\%) & Jumlah & (\%) & \\
\hline \multicolumn{6}{|l|}{ Kelompok umur } \\
\hline 31-40 tahun & 8 & 10,5 & 8 & 10,5 & 1 \\
\hline 41-50 tahun & 16 & 21,1 & 16 & 21,1 & 1 \\
\hline 51-60 tahun & 12 & 15,8 & 12 & 15,8 & 1 \\
\hline$>60$ tahun & 2 & 2,6 & 2 & 2,6 & 1 \\
\hline \multicolumn{6}{|l|}{ Pekerjaan } \\
\hline PNS & 2 & 2,6 & 4 & 5,3 & 0,375 \\
\hline Pegawai swasta & 11 & 14,5 & 17 & 22,4 & 0,107 \\
\hline Petani & - & - & 5 & 6,6 & 0,082 \\
\hline Ibu rumah tangga & 25 & 32,9 & 12 & 15,8 & \\
\hline \multicolumn{6}{|l|}{ Domisili } \\
\hline Kabupaten Singaraja & 1 & 1,3 & 1 & 1,3 & 1 \\
\hline Kabupaten Tabanan & 11 & 14,5 & 11 & 14,5 & 1 \\
\hline Kota Denpasar & 14 & 18,4 & 14 & 18,4 & 1 \\
\hline Kabupaten Gianyar & 2 & 2,6 & 2 & 2,6 & 1 \\
\hline Kabupaten Bangli & 2 & 2,6 & 2 & 2,6 & 1 \\
\hline Kabupaten Karangasem & 3 & 3,9 & 3 & 3,9 & 1 \\
\hline Lombok & 5 & 6,6 & 5 & 6,6 & 1 \\
\hline \multicolumn{6}{|l|}{ Pendidikan } \\
\hline $\mathrm{SD}$ & 13 & 17,1 & 9 & 11,8 & 0,511 \\
\hline SMP & 6 & 7,9 & 7 & 9,2 & 0,839 \\
\hline SMA & 18 & 23,7 & 15 & 19,7 & 0,672 \\
\hline Sarjana & 1 & 1,3 & 7 & 9,2 & 0,123 \\
\hline Jumlah & 38 & 100,0 & 38 & 100,0 & \\
\hline
\end{tabular}


Tabel 2 Crude OR faktor risiko kanker payudara di RSUP Sanglah Denpasar tahun 2013

\begin{tabular}{|c|c|c|c|c|}
\hline \multirow{2}{*}{$\begin{array}{l}\text { Kasus } \\
\text { Riwayat kehamilan }\end{array}$} & \multicolumn{2}{|c|}{ Kontrol } & \multirow{2}{*}{$\begin{array}{c}\text { OR } \\
1\end{array}$} & \multirow{2}{*}{$\frac{\mathbf{9 5} \% \mathbf{C I}}{0,063-15,988}$} \\
\hline & Tidak pernah hamil & Pernah hamil & & \\
\hline Tidak pernah hamil & 0 & 1 & & \\
\hline Pernah hamil & 1 & 36 & & \\
\hline Usia hamil pertama & $\geq 30$ tahun & $<30$ tahun & 1,4 & $0,444-4,411$ \\
\hline$\geq 30$ tahun & 0 & 5 & & \\
\hline$<30$ tahun & 7 & 26 & & \\
\hline Riwayat lama menyusui & $<1$ tahun & $\geq 1$ tahun & 1,375 & $0,553-3,419$ \\
\hline$<1$ tahun & 2 & 11 & & \\
\hline$\geq 1$ tahun & 8 & 17 & & \\
\hline $\begin{array}{l}\text { Riwayat penggunaan kontrasepsi } \\
\text { hormonal }\end{array}$ & $>12$ tahun & $\leq 12$ tahun & 0,16 & $0,007-3,900$ \\
\hline$>12$ tahun & 0 & 1 & & \\
\hline$\leq 12$ tahun & 6 & 31 & & \\
\hline Usia Menarche & $<12$ tahun & $\geq 12$ tahun & 0,88 & $0,355-2,177$ \\
\hline$<12$ tahun & 1 & 8 & & \\
\hline$\geq 12$ tahun & 9 & 20 & & \\
\hline $\begin{array}{l}\text { Riwayat kanker payudara pada } \\
\text { keluarga }\end{array}$ & $\begin{array}{c}\text { Ada keluarga dengan kanker } \\
\text { payudara }\end{array}$ & $\begin{array}{c}\text { Tidak ada keluarga dengan } \\
\text { kenker payudara }\end{array}$ & 8 & $1,839-34,794$ \\
\hline $\begin{array}{l}\text { Ada keluarga dengan kanker } \\
\text { payudara }\end{array}$ & 2 & 16 & & \\
\hline $\begin{array}{l}\text { Tidak ada keluarga dengan kenker } \\
\text { payudara }\end{array}$ & 2 & 18 & & \\
\hline Riwayat penyakit pada payudara & Sebelumnya ada infeksi & Sebelumnya tidak ada infeksi & 13,5 & $3,210-56,771$ \\
\hline Sebelumnya ada infeksi & 1 & 27 & & \\
\hline Sebelumnya tidak ada infeksi & 2 & 8 & & \\
\hline
\end{tabular}

\section{DISKUSI}

Hasil penelitian menunjukkan bahwa faktor yang dijumpai meningkatkan risiko kanker payudara berdasarkan analisis bivariat yaitu faktor riwayat keluarga dengan kanker payudara dan riwayat penyakit pada payudara. Berdasarkan analisis multivariat variabel yang secara bermakna meningkatkan risiko kanker payudara hanya riwayat penyakit pada payudara. Faktor risiko riwayat keluarga dengan kanker payudara yang signifikan pada analisis bivariat menjadi tidak signifikan pada analisis multivariat. Tujuan dari analisis multivariat adalah untuk mengetahui pengaruh beberapa faktor risiko secara bersamasama terhadap kejadian kanker payudara dan mengetahui faktor risiko yang paling dominan dari keseluruhan faktor risiko yang diteliti.

Berdasarkan hasil penelitian ini, terlihat bahwa faktor riwayat menyusui $<1$ tahun pada wanita yang berkunjung ke RSUP Sanglah Denpasar tidak merupakan faktor risiko terhadap kejadian kanker payudara dengan nilai $\mathrm{OR}=1,38$ (95\%CI: 0,553$3,419)$. Hasil penelitian ini tidak sejalan dengan beberapa penelitian lainnya yang menemukan bahwa lama menyusui berpengaruh terhadap kejadian kanker payudara. ${ }^{8,9} \mathrm{Hal}$ ini kemungkinan karena perbedaan populasi dan sampel penelitian.

Dalam literatur disebutkan bahwa hubungan antara variabel lama menyusui dengan kejadian kanker payudara dapat dijelaskan melalui beberapa mekanisme, salah satunya adalah karena pengaruh hormon setelah melahirkan. Hormon estrogen dan progesteron yang tinggi selama masa kehamilan akan menurun dengan tajam. Kadar hormon estrogen dan progesteron akan tetap rendah selama menyusui. Menurunnya kadar hormon estrogen dan hormon progesteron dalam darah selama menyusui akan mengurangi pengaruh hormon tersebut terhadap proses proliferasi jaringan termasuk jaringan payudara (biologic plausibility). Rendahnya proses proliferasi berhubungan dengan rendahnya kanker payudara. ${ }^{10}$

Hasil penelitian ini menunjukkan bahwa dalam analisis bivariat, faktor riwayat keluarga dengan kanker payudara pada wanita di RSUP 
Sanglah Denpasar meningkatkan risiko kejadian kanker payudara dengan nilai $\mathrm{OR}=8 \quad(95 \% \mathrm{CI}$ : 1,839-34,794). Ditemukannya beberapa anggota dalam satu keluarga yang menderita penyakit keganasan memberi petunjuk bahwa kanker payudara merupakan penyakit familial (Sindroma Li Fraumeni/LFS). Hasil penelitian ini selaras dengan penelitian lain, dimana didapatkan bahwa wanita dengan riwayat keluarga (dalam satu garis keturunan) ada yang menderita kanker payudara dan terdapat hyperplasia atipikal (AH) adalah kelompok yang berisiko tinggi. ${ }^{11}$ Penelitian ini juga selaras dengan penelitian lain yang menyatakan bahwa adanya riwayat keluarga dengan kanker payudara akan meningkatkan risiko kejadian kanker payudara. ${ }^{9}$

Hasil penelitian menemukan bahwa faktor riwayat penyakit pada payudara pada wanita di RSUP Sanglah Denpasar baik dalam analisis bivariat dan multivariat meningkatkan risiko kejadian kanker payudara dengan nilai OR=13,5 (95\%CI: 3,210-56,771). Hasil penelitian ini sejalan dengan beberapa penelitian lain yang menemukan bahwa penderita atau wanita yang pernah mengalami kelainan proliferatif memiliki risiko yang lebih besar untuk menderita kanker payudara. ${ }^{12} \mathrm{Hal}$ ini menunjukkan adanya konsistensi hasil dari beberapa penelitian.

Kejadian kelainan fibrokistik (benigna) mengalami peningkatan kejadian pada usia diatas 15 tahun kemudian frekuensinya turun setelah seseorang berumur 45 tahun. Walaupun terdapat perbedaan besar antara kurva insiden spesifik berdasarkan umur kelainan payudara benigna dan kanker payudara, telah ditunjukkan bahwa wanita yang menderita atau pernah menderita kelainan proliferatif memiliki peningkatan risiko untuk mengalami kanker payudara. Peningkatan risiko untuk terkena kanker payudara pada wanita dengan riwayat tumor jinak berhubungan dengan adanya proses proliferasi jaringan yang berlebihan tanpa adanya pengendalian kematian sel yang terprogram oleh proses apoptosis. Kondisi ini akan mengakibatkan timbulnya keganasan karena tidak adanya kemampuan untuk mendeteksi kerusakan pada DNA, sehingga sel abnormal akan berproliferasi secara terus menerus tanpa dapat dikendalikan. ${ }^{10,12}$

Beberapa variabel yang dicurigai sebagai faktor risiko ternyata ditemukan tidak bermakna dalam analisis statistik. Faktor risiko tentang riwayat tidak pernah mengalami proses kehamilan dalam penelitian ini terbukti tidak signifikan meningkatkan kejadian kanker payudara. Hal ini kemungkinan disebabkan karena sebagian besar sampel baik pada kelompok kasus maupun kontrol pernah mengalami riwayat kehamilan dan hanya satu responden yang belum menikah dan tidak pernah mengalami proses kehamilan. Hal ini kemungkinan yang mengakibatkan hasil analisis yang diperoleh tidak menunjukkan peningkatan risiko kanker payudara terkait proses kehamilan.

Secara teori risiko kanker payudara menunjukkan peningkatan seiring dengan peningkatan usia saat kehamilan pertama terutama wanita yang mengandung pada usia di atas 30 tahun. Hal lain yang berkaitan dengan kejadian kanker payudara adalah usia pertama kali seorang wanita melahirkan anak pertama. Jika seorang perempuan melahirkan saat berumur di atas 30 tahun maka risiko untuk mengalami kanker payudara semakin besar. Berdasarkan hasil penelitian yang dilakukan pada wanita Turki didapatkan bahwa wanita yang melahirkan pertama kali pada usia $\geq 30$ tahun meningkatkan risiko kanker payudara sebesar 1,36 $(95 \% \mathrm{CI}=1,07-2,48),{ }^{9,13,14}$

Hasil penelitian ini menunjukkan tidak ada hubungan yang signifikan antara riwayat usia hamil pertama di atas 30 tahun dengan kejadian kanker payudara. Hal ini kemungkinan disebabkan karena sebagian besar responden yang dijadikan sampel penelitian melahirkan pada usia di bawah 30 tahun serta sampel pada penelitian ini tidak dikelompokkan usianya untuk melihat berapa jumlah yang hamil pada setiap rentang umur namun hanya difokuskan pada usia diatas 30 tahun saja. Hal tersebut kemungkinan memberikan dampak tidak ditemukannya hubungan yang signifikan antara faktor usia hamil pertama $\geq 30$ tahun dengan kejadian kanker payudara.

Hasil penelitian ini juga menunjukkan bahwa riwayat penggunaan kontrasepsi hormonal yang lama ( $\geq 12$ tahun) tidak terbukti meningkatkan kejadian kanker payudara. Hasil ini kemungkinan disebabkan karena data yang diperoleh dalam penelitian ini menunjukkan sebagian besar responden menggunakan kontrasepsi hormonal $<12$ tahun dan ada pula yang tidak menggunakan kontrasepsi hormonal sehingga hasilnya tidak signifikan untuk meningkatkan kejadian kanker payudara. Secara teoritis selama periode penggunaan kontrasepsi hormonal, wanita mempunyai risiko $24 \%$ lebih tinggi terhadap kanker payudara. Penelitian ini sejalan dengan penelitian sebelumnya yang menunjukkan bahwa wanita yang menggunakan estrogen atau menerima terapi estrogen (menggunakan kontrasepsi hormonal) risikonya tidak terlalu signifikan untuk terjadinya kanker payudara dengan nilai $\mathrm{OR}=0,90$ $(95 \% \mathrm{CI}=0,50-1,48) .{ }^{9,15}$

Riwayat menarche dalam penelitian ini tidak terbukti dapat meningkatkan kejadian kanker 
payudara. Adanya perbedaan hasil antara penelitian ini dengan penelitian lain tentang riwayat menarche kemungkinan karena adanya kesulitan bagi responden untuk mengingat masa terdahulu yaitu sekitar lebih dari 10 tahun. Disamping itu, adanya kebiasaan/pola hidup responden, faktor genetik dan kejadian infeksi pada payudara akan sangat mempengaruhi kejadian kanker payudara. Berdasarkan data yang diperoleh menunjukkan sebagian besar responden menyatakan menstruasi pada usia $>12$ tahun sehingga hasilnya tidak signifikan untuk meningkatkan kejadian kanker payudara.

Kelemahan utama penelitian ini adalah sampel kasus dan kontrol yang dipilih secara purposif dan hanya yang datang ke Rumah Sakit Sanglah saja sehingga tidak mewakili kasus dan kontrol yang ada di populasi, sehingga validitas eksternalnya perlu ditingkatkan dalam penelitian selanjutnya. Selain itu, faktor risiko telah terjadi dalam waktu yang lama di masa lalu sehingga kemungkinan bahwa responden tidak begitu ingat dengan kejadiankejadian tersebut (bias recall).

Hasil penelitian ini dapat dijadikan sebagai data dasar tentang faktor-faktor yang dicurigai merupakan faktor risiko kanker payudara pada wanita. Selain itu, penelitian ini juga dapat dijadikan sebagai acuan bagi peneliti selanjutnya yang ingin meneliti hal yang sama yaitu faktor risiko kanker payudara dengan sampel kasus dan kontrol yang lebih mewakili populasi dan penggalian faktor risiko yang lebih akurat.

\section{SIMPULAN}

Variabel yang terbukti berhubungan secara bermakna dengan kejadian kanker payudara pada wanita adalah riwayat keluarga dengan kanker payudara dalam analisis bivariat dan riwayat adanya penyakit pada payudara dalam analisis multivariat. Variabel yang tidak terbukti meningkatkan risiko kanker payudara adalah faktor riwayat menyusui, riwayat kehamilan, riwayat hamil pertama $\geq 30$ tahun, riwayat penggunaan kontrasepsi hormonal dan usia menarche. Diharapkan bagi wanita agar melakukan deteksi dini kanker payudara dengan pemeriksaan payudara sendiri.

Bagi petugas rumah sakit, agar lebih intensif dalam mengadakan penyuluhan kesehatan terkait kanker payudara pada wanita. Lebih gencar mensosialisasikan tentang penyakit kanker payudara baik melalui media pamflet, media massa dan media elektronik. Bagi pengambil kebijakan, perlu dipikirkan mengenai keberadaan alat-alat yang digunakan untuk deteksi dini kanker payudara misalnya pemeriksaan mammografi di RSUP Sanglah Denpasar.

\section{UCAPAN TERIMA KASIH}

Ucapan terima kasih penulis sampaikan kepada Direktur RSUP Sanglah Denpasar karena telah memberikan ijin penelitian, seluruh responden yang telah berpartisipasi dalam penelitian ini serta semua rekan yang membantu terselesainya penelitian ini.

\section{DAFTAR PUSTAKA}

1. Kardinah. Kanker Payudara. http://www.fortunestar. co.id. 2005. Diakses pada tanggal 6 April 2010.

2. Tapan E. Kanker, antioksidan dan terapi komplementer. Jakarta: Elekmedia Komputindo; 2005

3. Landis SH, Murray T, Bolden S, Wingo PA. Cancer statistics 1998. CA Cancer J Clin 1998; 48: 6-31. Available:http:// www.cancer.gov/bcrisktool/. Diakses pada tanggal 9 Februari 2013.

4. Depkes RI. Jika tidak dikendalikan 26 juta orang di dunia menderita kanker. 2010. Available from: http// www.depkes.go.id/index.php/berita/press-release/1060 jika tidak dikendalikan 26 juta orang di dunia menderita kanker. Html. Diakses pada tanggal 8 januari 2012.

5. Pherson KMc, Steel CM, Breast Cancer Epidemiology Risk Factor and Genetic, BMJ 2010; Vol 321: 624-628

6. Putri N. Deteksi Dini Kanker Payudara. Yogyakarta: Aura Media; 2009.

7. Suddarth B. Keperawatan Medikal Bedah. Jakarta: EGC; 2000.

8. Budiningsih Y. Epidemiological analysis of risk factor for breast breast cancer in Indonesian females. Medical Journal of Indonesia 1995; 4: p. 163-168

9. Indrati R. Faktor-faktor risiko yang berpengaruh terhadap kejadian kanker payudara wanita; studi kasus di Rumah Sakit Dokter Kariadi Semarang. 2005. Diakses pada tanggal 22 Juni 2012.

10. Price, Andreson S. Gangguan Sistem Reproduksi Perempuan. Dalam Patofisiologi: Konsep klinis prosesproses penyakit. Jakarta: EGC; 2005.

11. Zhou WB, Xue DQ, Liu XA, Ding Q, Wang S. The influence of family history and histological stratification on breast cancer risk in women with benign breast disease: a meta analysis. J Cancer Res Clin Oncol 2011; 137: 1053-1060. Diakses pada tanggal 5 Januari 2013.

12. Dupont William D, Page David L. Risk Faktor for Breast Cancer in woman with Proliferative Breast Disease. 2004; 23: 469-478.

13. Soemitro, Monty P. Blak-Blakan Kanker Payudara: Temukan Sedini Mungkin. Bandung: Qanita; 2012.

14. Ulusoy C, Kepenekci I, Kose K, Anydinty S, Cam R. Applicability of the Gail model of breast cancer risk assessment in Turkish female population and evaluation of breast feeding as a risk faktor. Breast Cancer Research and Treatment 2010; 120: 419-424. Diakses pada tanggal 5 Januari 2013.

15. Bouchardy C, Benhamou S, Fioretta G, Verkoorjen HM, Chappuis PO, Caspar IN, et. al. Risk of second breast cancer according to estrogen receptor status and family history. Breast Cancer res Treat 2011; 127: 233-241. Diakses pada tanggal 5 Januari 2013.

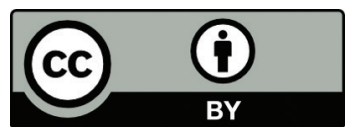

This work is licensed under a Creative Commons Attribution 